\title{
IDENTIFICATION OF SYNTOPIC ANURAN SPECIES IN EARLY TADPOLE STAGES: CORRESPONDENCE BETWEEN MORPHOMETRIC AND GENETIC DATA
}

\author{
ILIĆ, M. ${ }^{1}{ }^{*}$-STAMENKOVIĆ, G. ${ }^{1}$ - NiKOLIĆ, V. ${ }^{2}$ - MARKOVIĆ V. ${ }^{1}$ - MARINKOVIĆ N. ${ }^{1}$ - \\ PAUNOVIĆ M. ${ }^{1}$ - CRNOBRNJA-ISAILOVIĆ J., ${ }^{1,3}$ \\ ${ }^{1}$ Institute for Biological Research "Siniša Stankovic'", University of Belgrade, \\ Blvd Despota Stefana 142, 11000 Belgrade, Serbia \\ (phone: +38111207 8367; fax: +381112078 398) \\ ${ }^{2}$ Institute for Microbiology and Immunology, Faculty of Medicine, \\ University of Belgrade, Str. Dr. Subotića 1, 11000 Belgrade, Serbia \\ ${ }^{3}$ Faculty of science and mathematics, University of Niš, \\ Višegradska 33, 18000 Niš, Serbia \\ *Corresponding author \\ e-mail:marija.ilic@ibiss.bg.ac.rs \\ (Received $1^{\text {st }}$ Aug 2015; accepted $5^{\text {th }}$ Mar 2016)
}

\begin{abstract}
Many European frogs and toads are relatively secretive species and except during breeding season, adults can rarely be seen during time-restricted fieldwork. In contrast, their tadpoles are easy to record and could be very useful in a brief biodiversity assessment. It is important to perform quick and accurate taxonomic identification of tadpoles, yet genetic methods are costly and cannot be routinely applied. We tested suitability of morphometric analysis for taxonomical distinction among tadpoles of early breeding local anuran species. Tadpole samples were collected simultaneously at three different locations in Republic of Serbia (South-eastern Europe) in habitats known to be breeding sites shared by brown frogs and the common toad. DNA barcoding verified Rana dalmatina, R. temporaria and Bufo bufo species, each collected in different location. The results of linear morphometric analyses suggested that relative head length and head width could be good discriminative characteristics for tadpoles of these two Rana species and those of B. bufo. To distinguish between tadpoles of two analyzed brown frog species, relative tail length could be used. For further development of the identification procedures for tadpoles of particular species, it is essential to involve geometric morphometrics and to analyze different larval developmental stages.
\end{abstract}

Keywords: brown frogs, common toad, early breeders, taxonomic identification

\section{Introduction}

Analyses of tadpole morphology have been shown as very applicable in anuran taxonomy and phylogeny (Duelmann and Trueb, 1994; Sidorovska et al., 2002; Grosjean, 2005; Vejarano et al., 2006), but nowadays they become interesting also for conservation studies in a broadest sence (Buskirk, 2009; Severtsova et al., 2012; PujolBuxo, 2013; Schulze et al., 2015). Some anuran genera include morphologically similar and partly syntopic taxa and their species can be recognized mainly on the basis of genetic differences and differences in advertising calls (Larson and Chippindale, 1993). Moreover, many European frogs and toads are secretive crepuscular or nocturnal species so adults, except during the breeding season, can rarely be seen during short visits to the place (Arnold and Ovenden, 2002). In contrast to adult individuals, their tadpoles are easily detectable through the whole aquatic life stage (McDiarmid, 1994). In such cases, confident taxonomic identification of tadpoles is sometimes the only way 
to do quick and complete assessment of anuran fauna in the area of interest (Gascon, 1991). Although topics relating to ecological studies and environmental impact assessments are demanding, genetic methods still cannot be routinely applied due to restricted funds, which is a common problem in such studies.

Morphometric analysis of tadpoles has been widely used in interspecific comparisons, but often based on the ratios of total length or snout-vent length, where intra-specific and intra-populational variability should be taken into consideration (Sidorovska et al., 2002; Grosjean, 2005; Arendt, 2010). Regarding the tadpole's morphology, there are two phases with remarkable changes: before stage 25 and after stage 42 (McDiarmid and Altig, 1999). Many authors described various tadpole larval phases in their work (details in Lima and Pederassi, 2012) but most of these studies focus on the stages between 37 and 39 (Lima and Pederassi, 2012).

The aim of this paper was to evaluate the use of tadpole morphometric analysis for taxonomic distinction among locally-occurring syntopic, early-breeding anuran species. Unlike other studies, our work was focused on early development stages (hatchlings, stages 23 to 25, according to Gosner, 1960), as at this phase distinction among those species is sometimes difficult in the field (Arnold and Ovenden, 2002). The development of procedures for confident taxonomic identification of anuran tadpoles, including hatchlings, could help in more effective faunistic and ecological surveys of amphibians. This is particularly important in areas where the narrow zones of sympatry and occurrence of syntopy among various anuran species are recorded, such as in Republic of Serbia in South-eastern Europe (Dufresnes et al., 2013; Vukov et al., 2013).

\section{Material and Methods}

The brown frogs of genus Rana (family Ranidae) are among the earliest-breeding European anurans; the adults are mostly terrestrial, with an aquatic larval stage. Some European brown frog species spawn in fast highland streams (e.g. R. graeca in the Balkans; Arnold and Ovenden, 2002) but most breed in various types of stagnant or moderately fast-running waters, occurring in lowland habitats and at altitudes up to $2745 \mathrm{~m}$ a.s.l. in the Alps (Veith et al., 2003). It has been noted that Eurasian brown frogs are sometimes difficult to classify (Che et al., 2007) which is an issue particularly in the areas of syntopy.

Three species of brown frog, namely, Rana dalmatina, $R$. temporaria and $R$. graeca are common in South-east Europe (Sillero et al., 2014) with $R$. dalmatina and $R$. temporaria being widely distributed throughout Europe (Gasc et al., 1997; Arnold and Ovenden, 2002; Sillero et al., 2014). As noted in Hartel (2005), syntopic habitats of these two species are rare and interspecific competition may contribute to their niche separation (Riis, 1988). A study along the Târnava Valleys in Romania showed that the domination of $R$. dalmatina over $R$. temporaria was a common phenomenon in the lower to middle parts of the Valley, while in the upper section (>600 m elevation) $R$. temporaria began to dominate (Hartel, 2005). On the contrary, the long-term studies in Western Europe (Gollmann et al., 2002) showed an inverse relationship i.e. the domination of $R$. temporaria upon $R$. dalmatina (Hettyey and Pearman, 2003; Hartel, 2005). $R$. graeca is a brown frog species, endemic in the Balkan Peninsula, where it inhabits river gorges and canyons at altitudes from $300 \mathrm{~m}$ to $1000 \mathrm{~m}$ (Asimakopoulos, 1997).

We collected samples of tadpoles in early spring 2013 in three locations in Serbia, where the occurrence of brown frog species was common knowledge (Crnobrnja, 1982; 
Arnold and Ovenden, 2002; Tomašević et al., 2008). In Serbia, the agile frog $(R$. dalmatina) has a widespread distribution (Vukov et al., 2013). In contrast, the grass frog (R. temporaria) has a rather scattered distribution and for this reason is considered to be a species of conservation concern (Crnobrnja-Isailović and Paunović, 2015; Vukov et al., 2015). Both agile and grass frogs start breeding activities shortly after the snow has melted and their mating season ends quickly (Hartel, 2005; Iosob and Prisecaru, 2014; Crnobrnja-Isailović et al., 2015). $R$. graeca mostly breeds in cool and fast-running watercourses in hilly and mountainous areas (Arnold and Ovenden, 2002) and its occurrence in certain locations in Serbia overlaps with either $R$. dalmatina or $R$. temporaria (Vukov et al., 2013).

The common toad (Bufo bufo) is the only other anuran species in the area that breeds almost as early in the spring as brown frogs (Arnold and Ovenden, 2002). Both the eggs masses and the tadpoles of these two genera, Bufo and Rana, are easily distinguished (Arnold and Ovenden, 2002). However, it could not work on very early developmental stage: shortly after hatching, the tadpoles of brown frogs and the common toad could have similar appearance and cannot be taxonomicaly identified in situ by simple visual inspection.

\section{Description of sampling locations}

Geographic position of sampling locations is presented in Table 1 and Fig. 1 .

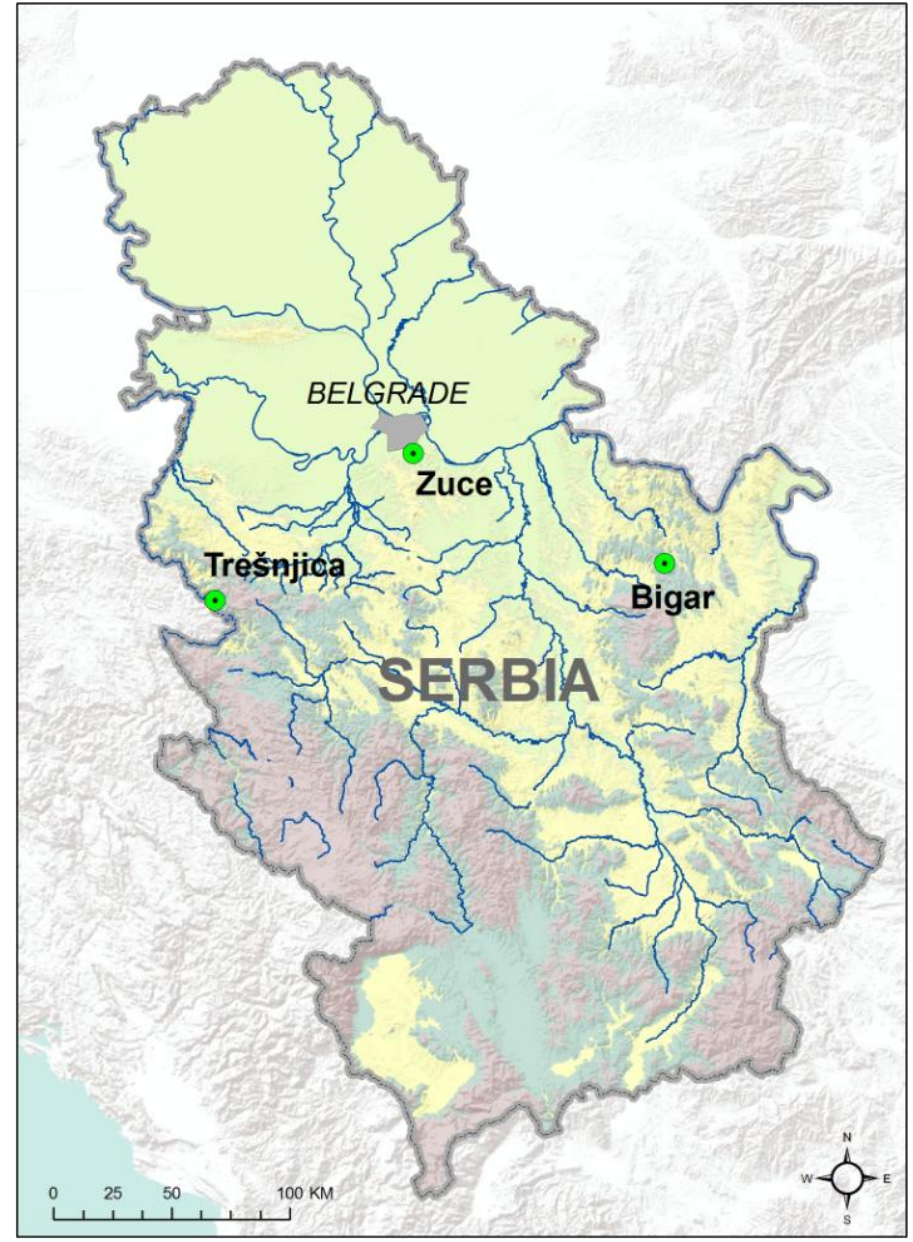

Figure 1. Geographic position of sampling locations. 
Table 1. Geografic coordinates of the sampling locations.

\begin{tabular}{|c|c|c|c|}
\hline Location & Longitude & Latitude & Altitude $(\boldsymbol{m})$ \\
\hline Zuce reservoir & $44^{\circ} 40^{\prime} 55.9^{\prime \prime}$ & $20^{\circ} 33^{\prime} 7.4^{\prime \prime}$ & 240 \\
Bigar Hill & $4^{\circ} 13^{\prime} 26^{\prime \prime}$ & $21^{\circ} 52^{\prime} 20^{\prime \prime}$ & 720 \\
Trešnjica River gorge & $4^{\circ} 07^{\prime} 18.46^{\prime \prime}$ & $19^{\circ} 29^{\prime} 57.3^{\prime \prime}$ & 200 \\
\hline
\end{tabular}

Each sampling location is distinctive regarding habitat characteristics and anthropogenic pressure. Lake Zuce, an artificial water reservoir, is situated in an agricultural area at the foot of Mountain Avala near the capital of Republic of Serbia, Belgrade, so the area is under considerable anthropogenic pressure. Geologically, Mt. Avala consists of limestone, marl, sandstone and serpentine rock. It is a conical hill, mostly covered by forest vegetation, both native and planted, trees including durmast oak (Quercus petraea), Turkish oak (Quercus cerris), hornbeam (Carpinus betulus), beech (Fagus sylvatica), linden (Tilia europaea), black pine (Pinus nigra) and black locust (Robinia pseudoacacia). Meadow vegetation is also present, but less extensive. The lake itself is surrounded by remnants of the deciduous forest (Tomašević et al., 2008). The only brown frog species recorded there is $R$. dalmatina (Crnobrnja-Isailović et al., 2012).

In comparison with the Zuce Reservoir, the other two sampling sites are under lower anthropogenic influence. The hilly-mountainous stream of Bigar is located on Bigar hill, part of the Homolje mountain range in eastern Serbia. The hill is composed of limestone and its vegetation consists of beech forest communties (Acero Carpinetum betuli [maple and hornbean]), Fagetum montanum (mountain beech) and Fagetum montanum subas, Corydalo Fagetum (community of beech with Holewort and Spring fumewort) and Acero Fagetum (beech with maple). In early spring, these communities are dominated by annual species, mostly ground flora, such as Corydalis solida, Corydalis cava, Dentaria bulbifera etc. Also, the area is covered in grassland, in the form of mowed meadows. The Bigar stream is one of the biggest permanent streams in this area. The stream bed is up to $1 \mathrm{~m}$ in width and $30 \mathrm{~cm}$ deep on average, and it joins with the Valja Saka stream to form the Jagnjilo River, which continues to flow to the north. Like all watercourses in this part of Serbia, Bigar stream belongs to the Danube Basin (Paunović et al., 2014). Two brown frog species occur in the area $-R$. dalmatina and $R$. temporaria (Crnobrnja, 1982).

Trešnjica River (2-3m in width and up to $50 \mathrm{~cm}$ deep) is located in western Serbia. This clean mountain river emerges below Povlen Mountain in western Serbia, and after $23 \mathrm{~km}$ it flows into the Drina River, also belonging to the Danube catchment. Immediately before joining the Drina, Trešnjica flows through a several-kilometre long limestone gorge, in places characteristic of a canyon valley. The vegetation mainly comprises Oriental hornbeam (Carpinus orientalis), Turkish oak (Quercus cerris), Italian oak (Quercus frainetto), black pine (Pinus nigra), prickly juniper (Juniperus oxycedrus), and several other thermophilous species. Trešnjica River gorge is one of Serbia's nature reserves (Amidzić et al., 2007). The only known brown frog species spawning in this river is $R$. graeca (Arnold and Ovenden, 2002). 


\section{Sampling procedure}

On every locality, ten individuals were gathered from the same aggregation of tadpoles by a standard deep or hand net, and they were preserved in $70 \%$ ethanol. In laboratory, tissue samples for genetic analyses (e.g. tip of the tail) were taken after measurement procedure and deposited in $95 \%$ ethanol. The collected tadpoles were in early development stages - hatchlings (stages 23 to 25, according to Gosner, 1960). Their body colour in all samples was black, while only specimens from Bigar Hill had visible external gills. Samples were deposited at the Department of Hydro-ecology and Water Protection, Institute for Biological Research "Siniša Stanković", University of Belgrade. Collection permit was issued by Ministry of Energetics, Development and Nature Protection of Republic of Serbia, No. 353-01-54/2013-08.

\section{DNA extraction, amplification and sequencing}

We have randomly chosen three of ten tadpoles from each locality from the same dense aggregation of tadpoles for genetic identification. Total DNA was extracted from $5 \mathrm{~mm}$ of tadpole's tail muscle, using the AccuPrep Genomic DNA Extraction kit, according to the manufacturer's instruction (Bioneer Corporation, Daejeon, R. Korea). The tissue was incubated in a tissue lysis buffer at $50^{\circ} \mathrm{C}$, for one hour. After precipitation and washing, DNA was eluted using a $75 \mathrm{microL}$ elution buffer. Depending on the species, an (approximately) $380 \mathrm{bp}$ fragment of mitochondrial $16 \mathrm{~S}$ rRNA gene was amplified by PCR with termalprofile and primers (16Sar: 5'-CG CCTGTTTATCAAAAACAT-3' 16Sbr: 5'-CCGG TCTGAACTCAGATCACGT-3') described in Veith et al. (2003). Special care was taken to ensure sterile conditions, and for each PCR run negative control (with water instead of a template) was used as a contamination check. Amplicons were sequenced in both directions using a BigDye ${ }^{\circledR}$ Terminator v3.1 Cycle Sequencing Kit (PE Applied Biosystems, Foster City, CA) and sequences were base called and assembled with ABI software: Sequencing Analysis 5.1 and SeqScape software, v 2.5. The obtained sequences were deposited in GenBank database (http://www.ncbi.nlm.nih.gov/genbank) under accession numbers KR136355 KR136364 (Appendix 1).

Additional sequences for analysis were downloaded from GenBank. All sequences were aligned by ClustalW (Thompson et al., 1994) and visually inspected in Bioedit 7.2.5 (Hall, 1999). A best-fit substitution model in aligned sequences was examined by JModelTest v.2.1.4. (Darriba et al., 2012) while phylogenetic analysis was conducted using MEGA 6.0 (Molecular Evolutionary Genetics Analysis software; Tamura et al., 2013). Tadpole species were identified using a DNA barcoding approach, based on sequenced $16 S$ rRNA gene part.

The Maximum Likelihood (ML) method, integrated in MEGA 6.0 software, was used to build a phylogenetic tree. Bootstrap analysis was done to determinate the strength of support for a clade on the phylogenetic tree.

The Bombina variegata species' sequence was used to root the tree.

\section{Morphometric analysis}

The tadpoles were placed in a Petri dish with constantly refreshed water, in order to avoid desiccation. The subjects' dorsal, lateral and ventral sides were photographed using a binocular magnifier Carl Zeiss, Stemi 2000-C with magnification 6.5 and a 
digital camera AxioCamERc 5s, Zeiss. ZEN 2011 software and ImageJ (Abramoff, 2004) were used for all measurements.

Morphometric characteristics used in subsequent analyses were chosen in accordance with available literature (Van Buskirk and Relyea, 1998; Sidorovska et al., 2002; Vences et al., 2002; Dey and Gupita, 2002; Grosjean, 2005; Vejarano et al., 2006; Altig, 2007; Arendt, 2010; Di Cerbo and Biancardi, 2010; Severtsova et al., 2012; Johansson and Richter-Boix, 2013). These were: ed - eye distance, hh - head height, e, - eye diameter, $\mathrm{tl}$ - tail length, $\mathrm{cc}$ - central tail muscle, th - tail height, $\mathrm{m}$ - mouth length, hwv - head width, hlv - head length and bl - body length. Measurements were standardized by body length (bl) to obtain standardized values for further analyses (ED - eye distance, $\mathrm{HH}$ - head height, $\mathrm{E}$ - eye diameter, TL - tail length, $\mathrm{CC}$ - central tail muscle, $\mathrm{TH}$ - tail height, $\mathrm{M}$ - mouth length, HWV - head width, HLV - head length).

The normality test (Shapiro-Wilk's test) was used to determine if the data set had normal distribution. Descriptive statistics were used to calculate various measurements, such as mean, standard deviation, minimum and maximum, range, median etc. of the obtained data. Levene's test of equality of variances between variables was used to assess homogenity of data (Levene, 1960). Test of equality of covariances (Box's test) (Box, 1949) was used to assess homogenity of covariance matrices. One-way ANOVA with contrasts was used to analyze the significance of differences between group means for tested variables. The linear regression was applied for modeling the relationships between tested variables. Pearson product-moment correlations were used to check linear correlation between analyzed variables. Uncorrelated variables were excluded from further multivariate analysis (Canonical Discriminant Analysis; CDA). The CDA was used to determine which variables discriminate analyzed data of these naturally cooccurring groups, and to visualize its relationships (Quinn and Keough, 2002; Young and Young, 1998; Simonović, 2004; Ivanović and Kalezić, 2009; Hair et al., 2010).

Performed statistical analysis were done by using the software package Statistica 7.0 (StatSoft, 2004).

\section{Results}

\section{Phylogenetic analysis}

The final dataset for phylogenetic analyses included 27 sequences from GenBank and 10 sequences obtained during our analysis (Appendix 1). As there is a lack of $R$. graeca sequences in GenBank, especially in the case of $16 \mathrm{~S} r R N A$ gene, we sequenced the tissue sample (a fingertip) collected earlier from one $R$. graeca adult from Serbia (Access no. KR136364). After careful examination, obtained sequences of $16 \mathrm{~S} r R N A$ gene, 421 - $537 \mathrm{bp}$ long, were cut to $348 \mathrm{bp}$ reliable sequence and used in phylogenetic analysis. The performed model test determined Tamura Nei model (1993) with invariant sites (TN93+I) as the most suitable. The maximum likelihood (ML) method produced a tree (Fig. 2) with good support for the analyzed species.

Two main clades were distinguished on obtained phylogenetic tree corresponding to analyzed Rana and Bufo gene sequences. The Rana clade included two subclades - one containing $R$. temporaria and the other with $R$. dalmatina and $R$. graeca. Within $R$. dalmatina, samples from Serbia formed a separate cluster, with good support from other analyzed conspecific sequences from Moldova, Spain, Germany and France. Within $R$. temporaria subclade, two main lineages were observed. Samples from Serbia were clustered with those from Spain, Czech Republic, Sweden, Russia and Ukraine. The 
other lineage contained conspecific sequences, mostly from the Western Europe. The Bufo bufo clade was well defined in the obtained tree (consider that B. bufo PT sequence information taken from the GenBank is in fact Bufo spinosus PT, due to taxonomic revision of Bufo bufo species group after the paper by Recuero et al., 2012). Besides samples from Greece, samples from Serbia also formed a separate cluster. We obtained uncosistent results regarding sample from Trešnjica river: DNA analysis showed that those tadpoles belong to B. bufo rather than to $R$. graeca what was expected based on geographical position and type of the breeding site.

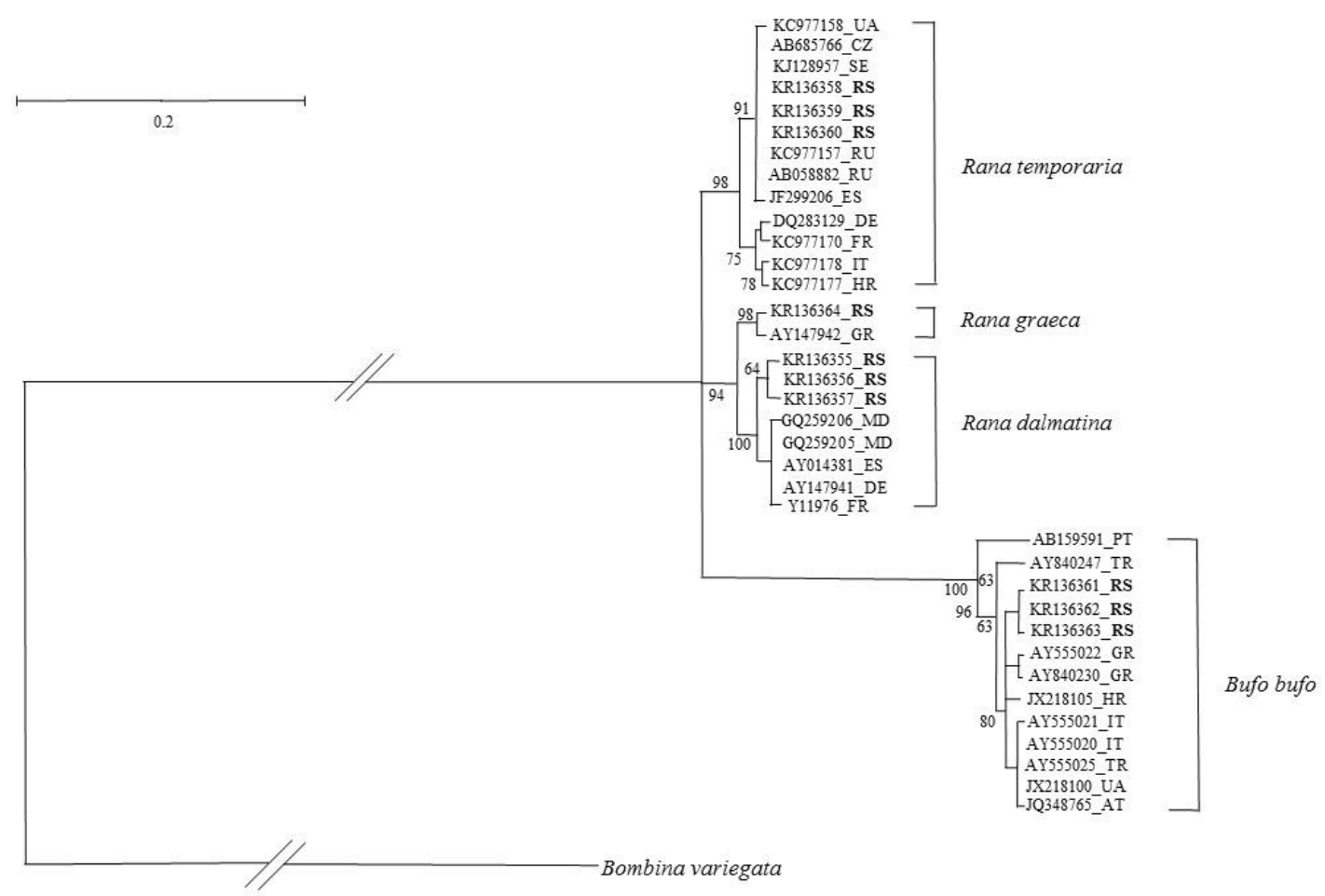

Figure 2. Phylogenetic analysis of $16 \mathrm{~S}$ rRNA gene fragment by Maximum Likelihood method based on the Tamura-Nei model. Bootstrap value $(<60 \%)$ was showed and confirmed the clade at the end of a branch.

\section{Morphometric analysis}

The value ranges of selected raw measurements are presented in Table 2.

Table 2. Value ranges of selected raw body measurements; $n$-sample size. Abbreviations of the variables are explained in Material and Methods. All the measurements were in mm.

\begin{tabular}{|c|c|c|c|c|c|}
\hline Species (n) & bl & hl & hw & tl & th \\
\hline R. dalmatina (10) & $10.08-11.27$ & $3.47-3.90$ & $1.60-2.05$ & $5.92-7.29$ & $1.64-2.46$ \\
R. temporaria (10) & $8.90-10.68$ & $2.75-4.20$ & $1.32-1.84$ & $4.91-6.27$ & $1.38-1.94$ \\
B. bufo (10) & $10.12-11.20$ & $4.04-4.70$ & $2.15-2.64$ & $5.61-6.44$ & $1.77-2.17$ \\
\hline
\end{tabular}


The measurements were further standardized by body length (bl) to obtain values for subsequent analyses (ED, HH, E, TL, CC, TH, M, HWV and HLV). Since the sample size was less than 50, Shapiro-Wilk's test was used to check the normality of data. In the tested data set, the obtained p-value was greater than the chosen alpha level $(\alpha=0.05)$, confirming that the analyzed data had a normal distribution.

The results of descriptive statistics (Fig. 3.) highlighted the similarity of ED and HH values among the analyzed Rana species, compared to B. bufo, suggesting that these two parameters could distinguish the two genera at early tadpole stages.

a)

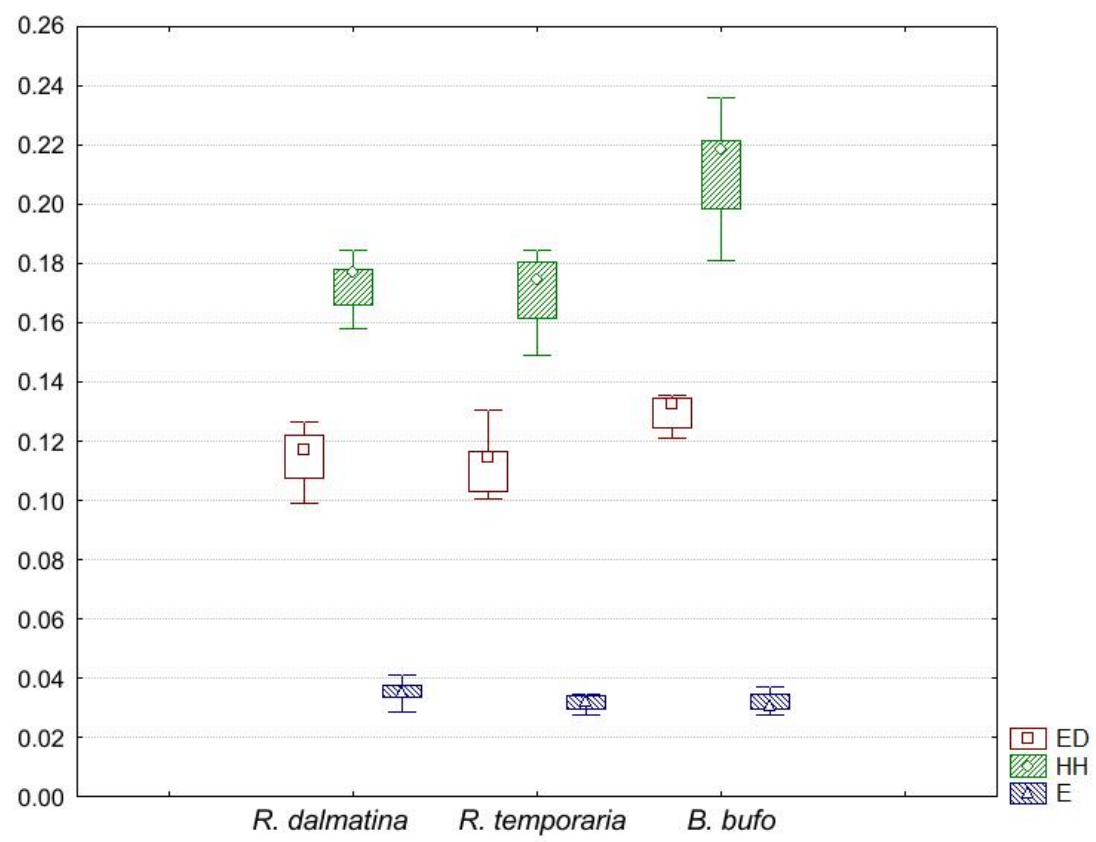

b)

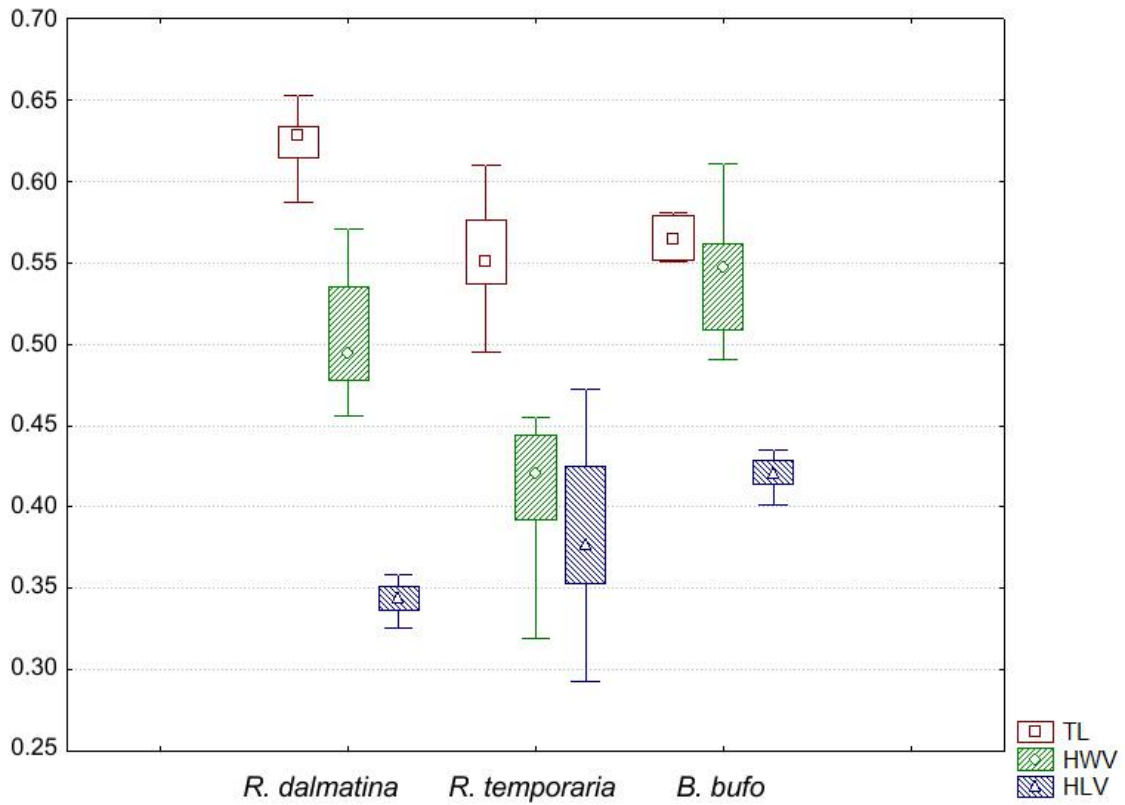


c)

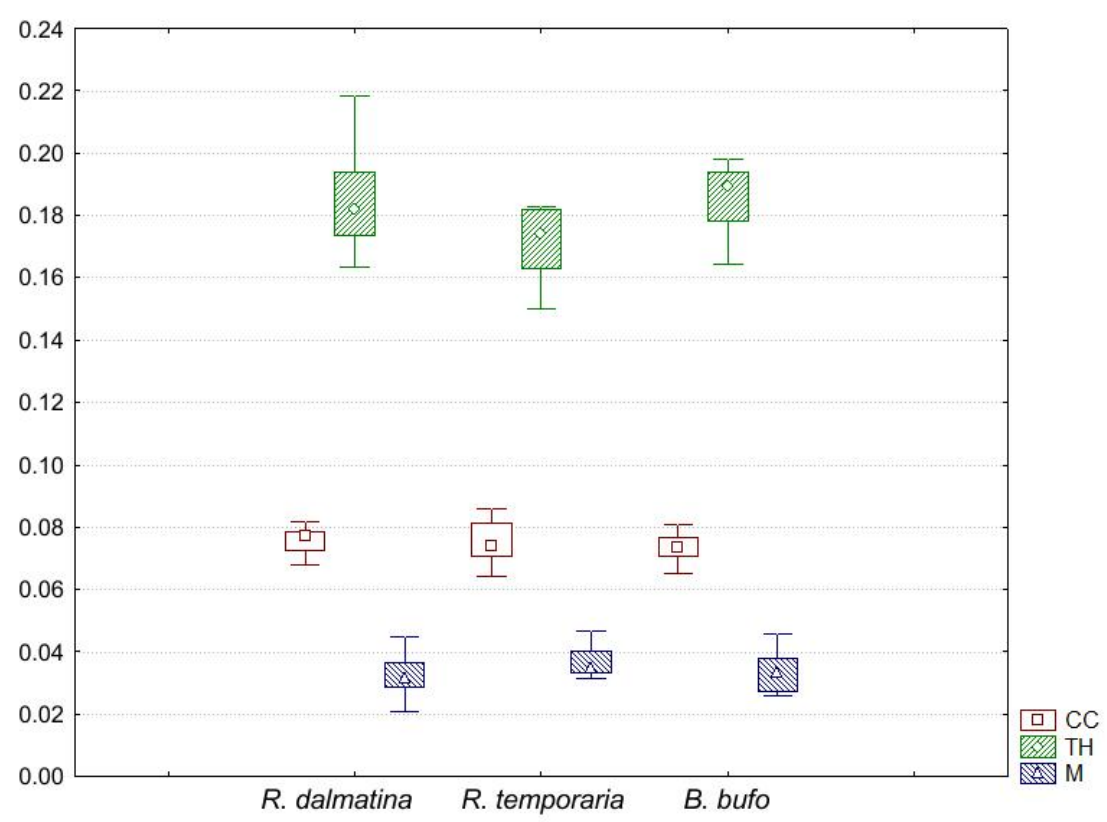

Figure 3. Descriptive statistics of the standardized measurements in tadpoles of analyzed anuran species: a) variable ED, $H H$ and $E$; b) variable $T L, H W V$ and $H V L ; c)$ variable $C C, T H$ and M. Abbreviations of the variables are explained in Material and Methods.

Moreover, TL, HLV and especially HWV differed in all three analyzed data sets. Thus, these parameters could be used in species recognition. It was notable that $\mathrm{E}, \mathrm{TH}$, $\mathrm{CC}$ and $\mathrm{M}$ values were relatively similar in all three data sets.

Performed tests of homogeneity (Levene's test and Box M test) showed homogeneity (equality of variances/covariances) for all tested variables with the exception of variable HLV.

To test statistical significance of differences between means of used variables (for analyzed species), one-way ANOVA with contrasts was applied. As it could be seen from Table 3, variables which differ significantly $(\mathrm{p}<0.05)$ among examined species, were ED, HH, TL, HWV and HLV.

Table 3. Results of one -way ANOVA with contrasts (significant differences $(p<0.05)$ are in bold); Estimate -Estimated mean value; Std. Err-Standard Error; $t-t$ value; $p-p$ value;

Cnf. Lmt (-95\%), Cnf. Lmt (+95\%) - Confidence Intervals for Mean.

\begin{tabular}{|c|c|c|c|c|c|c|}
\hline & Estimate & Std. Err & $\mathbf{t}$ & $\mathbf{p}$ & $\begin{array}{c}\text { Cnf. Lmt } \\
(-95 \%)\end{array}$ & $\begin{array}{c}\text { Cnf. Lmt } \\
(+95 \%)\end{array}$ \\
\hline ED & -0.032690 & 0.006351 & -5.14736 & 0.000021 & -0.045721 & -0.019659 \\
\hline HH & -0.085195 & 0.011152 & -7.63957 & 0.000000 & -0.108077 & -0.062314 \\
\hline$E$ & 0.003240 & 0.003502 & 0.925069 & 0.363125 & -0.003946 & 0.010425 \\
\hline TL & 0.047562 & 0.017595 & 2.703096 & 0.011736 & 0.011459 & 0.083665 \\
\hline $\mathrm{CC}$ & 0.005678 & 0.004581 & 1.239504 & 0.225825 & -0.003721 & 0.015078 \\
\hline $\mathrm{TH}$ & -0.016355 & 0.010192 & -1.60466 & 0.120203 & -0.037267 & 0.004558 \\
\hline $\mathrm{M}$ & 0.002175 & 0.005979 & 0.363826 & 0.718821 & -0.010092 & 0.014443 \\
\hline HWV & -0.156075 & 0.037526 & -4.15910 & 0.000290 & -0.233073 & -0.079078 \\
\hline HLV & -0.106239 & 0.025620 & -4.14680 & 0.000300 & -0.158806 & -0.053672 \\
\hline
\end{tabular}


Prior to applying multivariate analysis, Pearson's product-moment correlation was run to eliminate uncorrelated parameters. Eye diameter $(\mathrm{E})$, central tail muscle $(\mathrm{CC})$ and mouth length $(\mathrm{M})$ showed no correlation $(\mathrm{p}<0.05)$ and were thus excluded from further analysis (Table 4).

Table 4. Pearson correlations among tested variables (marked correlations that are significant at $p<0.05$ are in bold). Abbreviations of the variables are explained in Material and Methods.

\begin{tabular}{|c|c|c|c|c|c|c|c|c|c|}
\hline & ED & HH & $\mathbf{E}$ & TL & $\mathrm{CC}$ & TH & $\mathbf{M}$ & HWV & HLV \\
\hline ED & 1.000 & 0.450 & -0.047 & -0.314 & -0.244 & 0.065 & 0.135 & 0.320 & 0.413 \\
\hline $\mathrm{HH}$ & 0.450 & 1.000 & 0.004 & -0.225 & -0.114 & 0.365 & 0.091 & 0.576 & 0.453 \\
\hline E & -0.047 & 0.004 & 1.000 & 0.121 & 0.139 & -0.028 & -0.344 & -0.110 & 0.074 \\
\hline TL & -0.314 & -0.225 & 0.121 & 1.000 & 0.229 & 0.300 & -0.217 & 0.211 & -0.384 \\
\hline $\mathrm{CC}$ & -0.244 & -0.114 & 0.139 & 0.229 & 1.000 & 0.113 & 0.142 & 0.014 & -0.005 \\
\hline TH & 0.065 & 0.365 & -0.028 & 0.300 & 0.113 & 1.000 & 0.087 & 0.521 & -0.137 \\
\hline $\mathrm{M}$ & 0.135 & 0.091 & -0.344 & -0.217 & 0.142 & 0.087 & 1.000 & -0.077 & 0.088 \\
\hline HWV & 0.320 & 0.576 & -0.110 & 0.211 & 0.014 & 0.521 & -0.077 & 1.000 & -0.226 \\
\hline HLV & 0.413 & 0.453 & 0.074 & -0.384 & -0.005 & -0.137 & 0.088 & -0.226 & 1.000 \\
\hline
\end{tabular}

Canonical Discriminant Analysis (CDA) revealed that HWV and HLV are the most informative characters for taxonomical distinction between tadpoles of brown frogs and those of the common toad, while TL was considered the most informative for distinguishing between tadpoles of two brown frog species.

Table 5. The roots of the discriminant analysis (CDA), their discriminatory power and loads (the most discriminative variables are in bold).

\begin{tabular}{|c|c|c|}
\hline & Root 1 & Root 2 \\
\hline ED & -0.31469 & 0.480344 \\
\hline HH & -0.27051 & -0.075231 \\
\cline { 1 - 1 } TL & -0.19050 & $\mathbf{1 . 0 4 9 5 1 7}$ \\
\cline { 1 - 1 } TH & -0.11888 & 0.113444 \\
\cline { 1 - 1 } HWV & $\mathbf{- 0 . 6 6 5 3 9}$ & 0.068916 \\
\cline { 1 - 1 } HLV & $\mathbf{- 0 . 8 3 7 1 2}$ & -0.426270 \\
\cline { 1 - 1 } Eigenval & 12.58955 & 3.311605 \\
\cline { 1 - 1 } Cum.Prop & 0.79174 & 1.000000 \\
\hline
\end{tabular}

The complex relationship among selected morphometric parameters in analyzed tadpole samples was presented in two-dimensional space of first and second discriminant axes (Fig. 4.).

The first axis (root) distinguished $B$. bufo (to the left of the graph) from genus Rana (to the right of the graph). Distinction of the analyzed Rana species occurred along the second root.

Linear regression analysis was used for a detailed investigation of the relationship between the most significant variables, by canonical discriminant analyses (HLV, HWV 
and TL). As values of the coefficient of determination $\left(\mathrm{r}^{2}\right)$ were low $(<0.3)$, only the TL/HWV relationship was presented on the graph (Fig. 5).

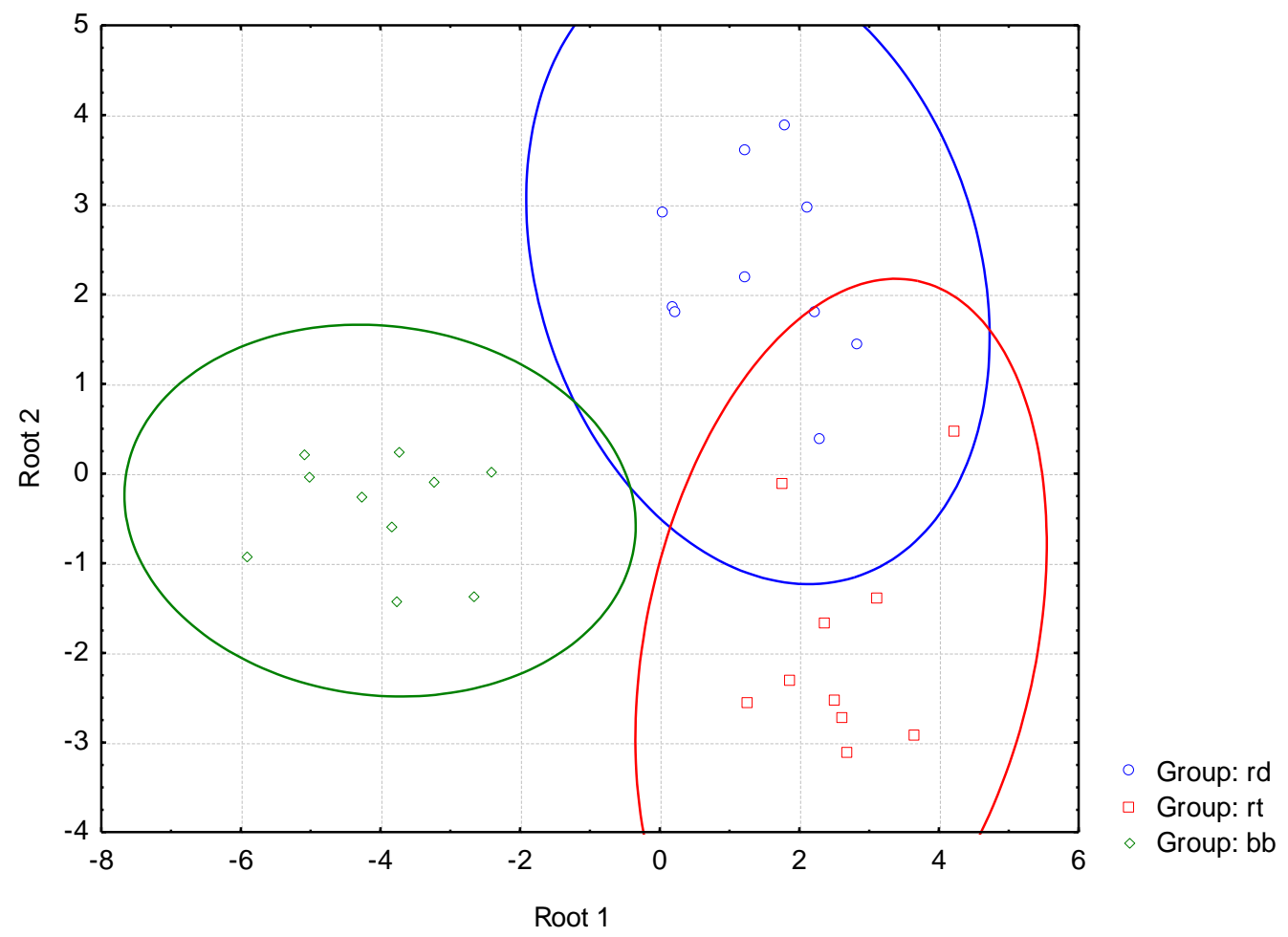

Figure 4. Canonical Discriminant Analysis: $r d-R$. dalmatina, $r t-R$. temporaria, bb-B. bufo.

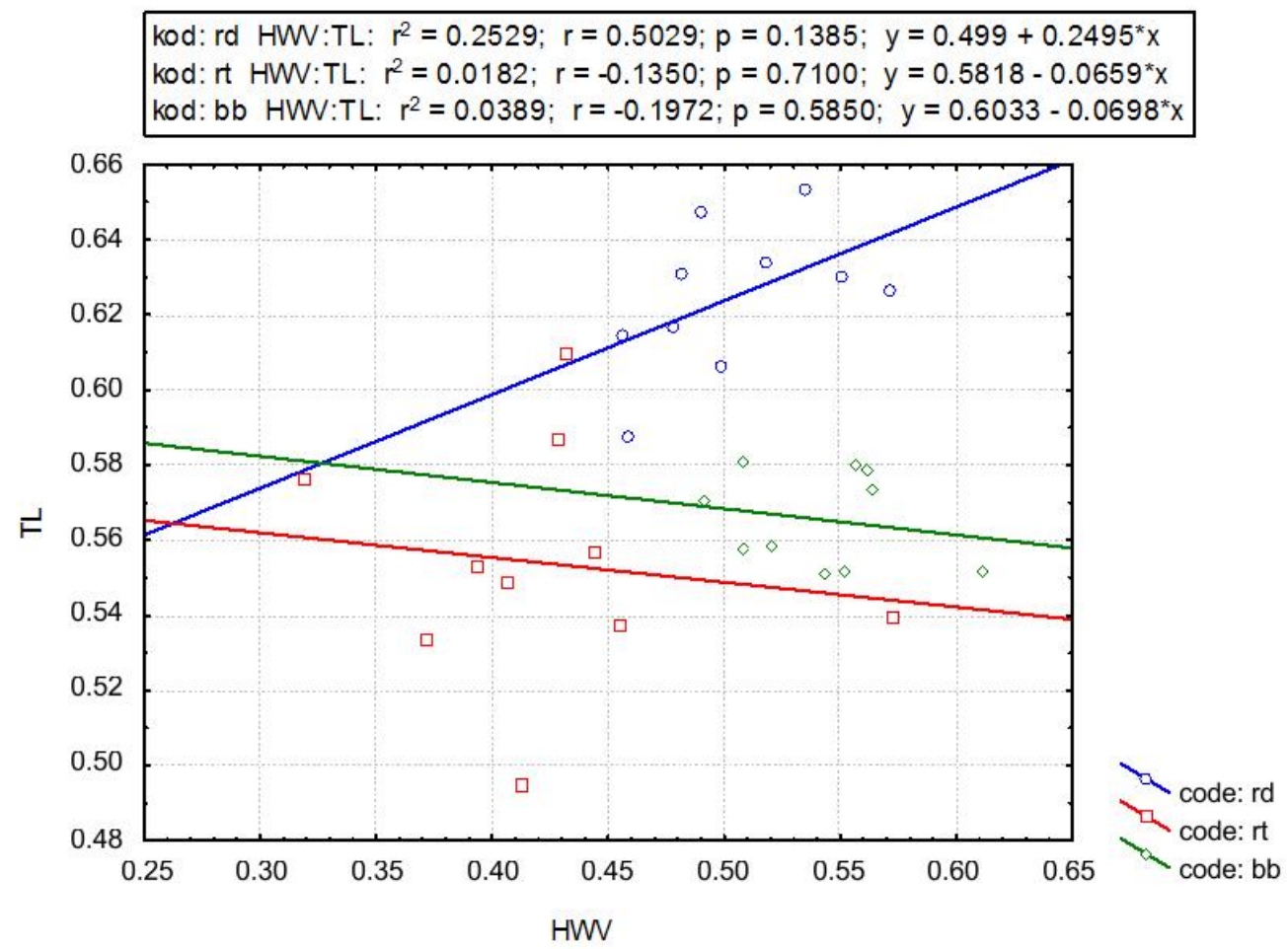

Figure 5. Regression analysis of head width (HWV) on tail length (TL); $r d-R$. dalmatina, $r t-$ R. temporaria, $b b-B$. bufo. 
It was notable that $R$. dalmatina showed a positive correlation, in contrast to the negative one occurring in $R$. temporaria and $B$. bufo. The best approximation with a linear regression line was observed in $R$. dalmatina $\left(\mathrm{r}^{2}=0.25\right)$, while the weakest one was detected in $R$. temporaria (coefficient of determination was 0.01 ).

\section{Discussion}

Gene sequence, based on $16 \mathrm{~S} r R N A$ gene, confirmed the morphological identification of the analyzed species. The obtained phylogenetic tree showed that the $R$. temporaria clade was the most heterogeneous, as mentioned previously in the work of Reh and Seitz (1990) and Vences et al. (2013). Further, analyzed sequences from Serbia were shown to be closer to the North-Eastern group (samples form Czech Republic, Russia, Ukraine and Sweden) than to specimens from the South and Western group (samples from Croatia and Italy). A similar relation was detected in another typical boreal species e.g. Zootoca vivipara (ex Lacerta vivipara), where Surget-Groba et al. (2001) showed a closer similarity between Bulgarian populations and East European ones than with adjacent parts of the Balkan Peninsula and Western Europe (Crnobrnja-Isailović, 2007). Although the common frogs' postglacial re-colonization of Europe was not as straightforward as had been previously assumed, with numerous small, cryptic refugia (Teacher et al., 2009), our results could denote Serbia as one of these refugia (or recolonization hotspots) in the case of North-East Europe.

$R$. dalmatina samples from Serbia were well separated from others collected in Spain, Moldova, France and Germany. In the B. bufo clade, samples from Serbia were placed together with those from Greece, Italy, Austria and Croatia, but somewhat apart from the sample from Portugal, being in line with the results of Recuero et al. (2012) who revealed that common toads from the Iberian Peninsula belong to B. spinosus, while Appenine, Central European and Balkan ones represent B. bufo.

Descriptive statistics and one-way ANOVA showed fewer differences in samples of $R$. dalmatina and $R$. temporaria tadpoles in comparison with $B$. bufo. Canonical Discriminant Analysis showed that the most useful measures for distinguishing tadpoles of the three analyzed species were body size standardized tail height (TL), head width (HWV) and head length (HLV). Relative head size is a determinative characteristic for distinguishing between Rana sp. and $B$. bufo, while the relative tail length is the most informative for distinguishing between the two Rana species. Additionally, in all cases linear regression analysis of the most informative variables (HLV, HWV and TL) showed a separation of $R$. dalmatina from the other two analyzed species, while the coefficient of determination $\left(\mathrm{r}^{2}\right)$ was low in all cases.

Furthermore, we learned from this study that $B$. bufo and $R$. graeca tadpoles could be visually misidentified at very early developmental stages if they occur syntopically in highland running waters in the early spring (a common spawning type for the Greek frog but not so usual for the Common toad). Our further analysis will include comparison of the same morphometric measures used in this study, taken simultaneously from tadpoles of all three brown frog species and the common toad, all raised in the laboratory from fertilized eggs collected in the natural habitat in order to follow, compare and detect significant allometric changes occuring within and among three species. Additionally, our future plans include also a comparative body shape analysis on samples of three species of brown frogs and the common toad, done at several stages of tadpole development by using geometric morphometrics. 
Acknowledgements. We would like to thank Dr. Zoran Gačić on his advices and suggestions on the manuscript, as well as to Mrs Esther Helajzen for linguistic improvement. We are also indebted to two anonymous referees for their helpful comments. This study was supported by the Ministry of Education, Science and Technological Development of Republic of Serbia, Grants TR 037009, III 043002, OI 173025 and 175024.

\section{REFERENCES}

[1] Abramoff, M. D., Magalhaes, P. J., Ram, S. J. (2004): "Image Processing with ImageJ". Biophotonics International 11: 36-42.

[2] Altig, R. (2007): A primer for the morphology of anuran tadpoles. - Herpetological Conservation and Biology 2(1):71-74.

[3] Amidzić, L., Krasulja. S., Belij, S. (2007): Protected natural resources in Serbia. Ministry of environmental protection and institute for nature conservation of Serbia. Belgrade.

[4] Arendt, J. (2010): Morphological correlates of sprint swimming speed in five species of spadefoot toad tadpoles: comparison of morphometric methods. - Journal of Morphology 271(9): 1044-1052.

[5] Arnold, E.N., Ovenden, D.W. (2002): Reptiles and Amphibians of Europe, Princeton University Press, New Jersey.

[6] Asimakopoulos, B. (1997): Rana graeca Boulenger, 1891. - In: Gasc J.P., Cabela A., Crnobrnja-Isailovic, J., Dolmen, D., Grossenbacher, K., Haffner, P., Lescure, J., Martens, H., Martínez Rica J.P., Maurin H., Oliveira M.E., Sofianidou T.S., Veith M. \& Zuiderwijk A. (eds) Atlas of amphibians and reptiles in Europe, Collection Patrimoines Naturels, Societas Europaea Herpetologica, Muséum National d'Histoire Naturelle \& Service du Patrimoine Naturel, Paris.

[7] Box, G. E. P. (1949): A General Distribution Theory for a Class of Likelihood Criteria. Biometrika 36(3/4): 317-346.

[8] Van Buskirk, J. (2009): Natural variation in morphology of larval amphibians: phenotypic plasticity in nature? - Ecological Monographs 79: 681-705.

[9] Che, J., Pang, J., Zhao, E., Matsui, M. and Zhang, Y. (2007): Phylogenetic relationships of the Chinese brown frogs (genus Rana) inferred from partial mitochondrial $12 \mathrm{~S}$ and 16S rRNA gene sequences. - Zoological Science 24: 71-80.

[10] Crnobrnja, J. (1982): Faunistic notes on amphibians and reptiles of Homolje. In: Homolje '81. Results of biological research. Young Researches of Serbia, Belgrade.

[11] Crnobrnja-Isailović, J. (2007): Cross - section of a refugium: genetic diversity of amphibian and reptile populations in the Balkans. - In: Weiss, S., Ferrand, N. (eds.) Phylogeography of Southern European refugia. Springer, The Netherlands.

[12] Crnobrnja-Isailović, J., Milojković, D., Macura, B. (2015): Amphibians and reptiles of Djerdap. PE Djerdap National Park, Donji Milanovac, Serbia, 192.

[13] Crnobrnja-Isailović, J., Paunović, M. (2015): Conservation and decline of European amphibians: The Republic of Serbia. - In: Heatwole, H., Wilkinson, J. (eds.) Status of conservation and decline of amphibians: Eastern Hemisphere: Southeastern Europe and Turkey. Pelagic Publishing, UK.

[14] Crnobrnja-Isailović, J., Jelić, I., Stanisavljević, B., Ćosić. N. (2012): Vodozemci i gmizavci Beograda. Endemit, Beograd.

[15] Darriba, D., Taboada, G.L., Doallo, R. and Posada, D. (2012): jModelTest 2: more models, new heuristics and parallel computing. - Nature Methods 9(8): 772.

[16] Dey, M., Gupita, A. (2002): A note on morphometry of tadpole and adult of Microhyla ornata (Dumeril \& Bibron) (Anura: Microhylidae). - Zoos' Print J. 17 (12): 951-953.

[17] Di Cerbo, A. R., Biancardi, C. M. (2010): Morphometric study on tadpoles of Bombina variegata (Linnaeus, 1758) (Anura; Bombinatoridae). - Acta Herpetologica 5(2): 223231. 
[18] Dufresnes, C., Wassef, J., Ghali, K., Brelsford, A., Stöck, M., Lymberakis, P., CrnobrnjaIsailović, J., Perrin, N. (2013): Conservation phylogeographics: does historical diversity account for regional vulnerability in European tree frogs (Hyla arborea)? - Molecular Ecology 22: 5669-5684.

[19] Gasc, J. P., Cabela, A., Crnobrnja-Isailovic, J., Dolmen, D., Grossenbacher, K., Haffner, P., Lescure, J., Martens, H., Martínez Rica, J. P., Maurin, H., Oliveira, M. E., Sofianidou, T. S., Veith, M., Zuiderwijk, A. (eds) (1997): Atlas of amphibians and reptiles in Europe, Collection Patrimoines Naturels, Societas Europaea Herpetologica, Muséum National d'Histoire Naturelle \& Service du Patrimoine Naturel, Paris, 496.

[20] Gascon, C. (1991): Population- and community-level analyses of species occurrences of central Amazonnian rainforest tadpoles. - Ecology 72: 1731-1746.

[21] Gollmann, G., Gollmann, B., Baumgartner, C., and Waringer-Löschenkohl, A. (2002): Spawning site shifts by Rana dalmatina and Rana temporaria in response to habitat change. - Biota 3/1-2: 35-42.

[22] Gosner, K.L. (1960): A simplified table for staging anuran embryos and larvae with notes on identification. - Herpetologica 16: 183-190.

[23] Grosjean, S. (2005): The choice of external morphological characters and developmental stages for tadpole-based anuran taxonomy: a case study in Rana (Sylvirana) nigrovittata (Blyth, 1855) (Amphibia, Anura, Ranidae). - Contributions to Zoology 74 (1/2): 61-76.

[24] Hall, T. A. (1999): BioEdit - A user-friendly biological sequence alignment editor and analysis program for Windows 95/98/NT. Nucleic Acids Symposium Series 41: $95-98$.

[25] Hair, J. F., Black, W. C., Babin, B. J., Anderson, R. E. (2010): Multivariate data analysis. Upper Saddle River, NJ: Pearson Prentice Hall.

[26] Hartel, T. (2005): Aspects of breeding activity of Rana dalmatina and Rana temporaria reproducing in a seminatural pond. - North-Western Journal of Zoology 1: 5-13.

[27] Hettyey, A., Pearman P. B. (2003): Social environment and reproductive interference affect reproductive success in the frog Rana latastei. - Behavioural Ecology 14(2): 294300 .

[28] Iosob, G. A., Prisecaru, M. (2014): Observations on the life cycle and reproductive behavior in Rana dalmatina F. - Biologie 23/2: 50-59.

[29] Ivanović, A., Kalezić, M. (2009): Evoluciona morfologija: Teorijske postavke i geometrijska morfometrija. - Biološki fakultet, Beograd.

[30] Johansson, F., Richter-Boix, A. (2013): Within-population developmental and morphological plasticity is mirrored in between-population differences: linking plasticity and diversity. - Evolutionary biology 40(4): 494-503.

[31] Larson, A., Chippindale, P. T. (1993): Molecular approaches to the evolutionary biology of plethodontid salamanders. - Herpetologica 49: 204-215.

[32] Levene, H. (1960): Robust tests for equality of variances 1 . Contributions to probability and statistics: Essays in honor of Harold Hotelling (2): 278-292.

[33] Lima, M. S. C. S., Pederassi, J. (2012): Morphometrics and ratio of body proportionality of tadpoles of Rhinella icterica (Anura, Bufonidae) at different development stages. Brazilian Journal of Biology 72.3: 623-629.

[34] McDiarmid, R. W. (1994): Amphibian diversity and natural history: An Overview. - In: Heyer, W. R., Donnelly, M. A., McDiarimid, R. W., Hayek, L.-A. C., Foster, M. S.: Measuring and monitoring biological diversity. Standard methods for amphibians. Smithsonian Institutuion Press. Washington and London.

[35] McDiarmid, R. W., Altig, R. (1999): Tadpoles: the biology of anuran larvae. - The University of Chichago Press, Chichago.

[36] Paunović, M., Karadžić, B., Mitrović, M., Pavlović, P., Simić, V., Simonović, P., Vuković-Gačić, B., Jakšić, P., Perić-Mataruga, V., Crnobrnja-Isailović, J., Jarić, S., Marinković, S., Ćosić, N., Ilić, M., Atanacković, A., Vasiljević, B., Tomović, J., Marković, V., Pavlović, D., Pavlović, M., Tubić, B., Zorić, K., Kračun, M., Kolarević, S. (2014): "Ecological Baseline Report for two mining project - Avala - the Timok Gold 
Project (Eastern Serbia). University of Belgrade, Institute for Biological Research "Siniša Stanković" and Avala Resources, Belgrade.

[37] Pujol-Buxó, E., San Sebastián, O., Garriga, N., Llorente, G. A. (2013): How does the invasive/native nature of species influence tadpoles' plastic responses to predators? Oikos, 122(1): 19-29.

[38] Quinn, G. P., Keough, M. J. (2002): Experimental design and data analysis for biologists. - Cambridge University Press.

[39] Recuero, E., Canestrelli, D.,Voros, J., Szabo, K., Poyarkov, N. A., Arntzen, J. W., Crnobrnja-Isailović, J., Kidov, A. A, Cogalniceanu, D., Caputo, F. P., Nascetti, G., Martinez-Solano, I. (2012): Multilocus species tree analyses resolve the radiation of the widespread Bufo bufo species group (Anura, Bufonidae). - Molecular Phylogenetics and Evolution 62: 71-86.

[40] Reh, W, Seitz, A. (1990): The influence of land use on the genetic structure of populations of the common frog Rana temporaria. - Biological Conservation 54: 239250.

[41] Riis, N. (1988): The present distribution of Rana dalmatina and Rana temporaria in Southern Scandinavia explained by a theory of competitive exclusion. - Mem. Soc. Fauna Flora Fennica 64: 104-106.

[42] Schulze, A., Jansen, M., Köhler, G. (2015): Tadpole diversity of Bolivia's lowland anuran communities: molecular identification, morphological characterisation, and ecological assignment. - Zootaxa 4016 (1):1-111.

[43] Severtsova, E. A., Gutiérrez, D. R. A., Severtsov, A. S. (2012): Morphometry as a Method of Studying Adaptive Regulation of Embryogenesis in Polluted Environments. In: Dr. Ken-Ichi Sato (ed.) Embryogenesis, InTech, Rijeka, Croatia.

[44] Sidorovska, V., Ljubisavljevic, K., Džukić, G., Kalezić, M. L. (2002): Tadpole morphology of two spadefoot toads (Pelobates fuscus and P. syriacus) (Amphibia, Anura, Pelobatidae). - Spixiana 25: 183-191.

[45] Sillero, N., Campos, J., Bonardi, A., Corti, C, Creemers, R., Crochet, P.-A., Crnobrnja Isailović, J., Denoël, M., Ficetola, G. F., Gonçalves, J., Kuzmin, S., Lymberakis, P., de Pous, P., Rodríguez , A., Sindaco, R., Speybroeck, J., Toxopeus, B., Vieites, D.R., Vences, M. (2014): Updated distribution and biogeography of amphibians and reptiles of Europe. - Amphibia-Reptilia 35: 1-31.

[46] Simonović, P. D. (2004): Principi zoološke sistematike. - Zavod za udžbenike i nastavna sredstva, Beograd.

[47] StatSoft, Inc. (2004). STATISTICA (data analysis software system), version 7. www.statsoft.com.

[48] Surget-Groba, Y., Heulin, B., Guillaume, C.-P., Thorpe, R. S., Kupriyanova, L., Vogrin, N., Maslak, R., Mazzoti, S., Venczel, M., Ghira, I., Odierna, G., Leontyeva, O., Monney, J.-C., Smith, N. (2001): Intraspecific phylogeography of Lacerta vivipara and the evolution of viviparity. - Molecular Phylogenetics and Evolution 18: 449-459.

[49] Tamura K., Nei, M. (1993): Estimation of the number of nucleotide substitutions in the control region of mitochondrial DNA in humans and chimpanzees. - Molecular Biology and Evolution 10: 512-526.

[50] Tamura K., Stecher G., Peterson D., Filipski A., Kumar S. (2013): MEGA6: Molecular Evolutionary Genetics Analysis version 6.0. - Molecular Biology and Evolution 30: 2725-2729.

[51] Teacher, A. G. F., Garner, T. W. J., Nichols, R. A. (2009): European phylogeography of the common frog (Rana temporaria): routes of postglacial colonization into the British Isles, and evidence for an Irish glacial refugium. - Heredity 102(5): 490-496.

[52] Thompson, J. D., Higgins D. G., Gibson T. J. (1994): CLUSTAL W: improving the sensitivity of progressive multiple sequence alignments through sequence weighting, position specific gap penalties and weight matrix coice. - Nucleic Acids Research 22: 4673-4680. 
[53] Tomašević, N., Cvetković, D., Aleksić, I., Miaud, C., Crnobrnja Isailović, J. (2008): Interannual variation in life history traits between neighbouring populations of the widespread amphibian Bufo bufo. - Revue d'écologie 63: 73-83.

[54] Van Buskirk, J., Relyea, R.A. (1998): Selection for phenotypic plasticity in Rana sylvatica tadpoles. - Biological Journal of the Linnean Society 65: 301-328.

[55] Veith, M., Kosuch, J., Vences, M. (2003): Climatic oscillations triggered post-Messinian speciation of Western Palearctic brown frogs (Amphibia, Ranidae). - Molecular phylogenetics and evolution 26(2): 310-327.

[56] Vejarano, S., Thomas, M., Vences, M. (2006): Comparative tadpole morphology in three species of frogs of the genus Spinomantis (Amphibia: Mantellidae). - Contributions to Zoology 75: 99-108.

[57] Vences, M., Nieto, M.P.S., Vieites D.R. (2002): Phenotypic plasticity of anuran larvae: environmental variables influence of body shape and oral morphology in Rana temporaria tadpoles. - Journal of Zoology (London) 257: 155-162.

[58] Vences, V., Hauswaldt S. J., Steinfartz, S., Rupp, O., Goesmann, A., Künzel, S., OrozcoterWengel, P., Vieites, D. R, Nieto-Roman, S., Haas, S., Laugsch, C., Gehara, M., Bruchmann, S., Pabijan,M., Ludewig, A., Rudert, D., Angelini, C., Borkin, L. J., Crochet, P., Crottini, P., Dubois, A., Ficetola G.F., Galan, P., Geniez, P., Hachtel, M., Jovanovic, O., Litvinchuk, S. N., Lymberakis, P., Ohler, A., Smirnov N. A. (2013): Radically different phylogeographies and patterns of genetic variation in two European brown frogs, genus Rana. - Molecular Phylogenetics and Evolution 68: 657-670.

[59] Vukov, T., Kalezić, L. M., Tomović, Lj., Krizmanić, I., Jović, D., Labus, N., Džukić, G. (2013): Amphibians in Serbia - Distribution And Diversity Patterns. - Bulletin of the Natural History Museum 6: 90-112.

[60] Vukov, T., Tomović, Lj., Krizmanić, I., Labus, N., Jović, D., Džukić, G., Kalezić, L. M. (2015): Conservation Issues of Serbian Amphibians Identified from Distributional, Life History and Ecological Data. - Acta Zoologica Bulgarica 67: 105-116.

[61] Young, L.J., Young, J. (1998): Statistical ecology. - Springer Science \& Business Media, New York. 


\section{APPENDIX}

Appendix 1. The list of sequences that were used in the analyses (GenBank accession numbers and countries of origin).

\begin{tabular}{|c|c|c|}
\hline Species & Country & Access no. \\
\hline Rana dalmatina & Serbia & KR136355 \\
\hline Rana dalmatina & Serbia & KR136356 \\
\hline Rana dalmatina & Serbia & KR136357 \\
\hline Rana dalmatina & Germany & AY147941 \\
\hline Rana dalmatina & France & Y11976 \\
\hline Rana dalmatina & Spain & AY014381 \\
\hline Rana dalmatina & Moldova & GQ259206 \\
\hline Rana dalmatina & Moldova & GQ259205 \\
\hline Rana graeca & Serbia & KR136364 \\
\hline Rana graeca & Greece & AY147942 \\
\hline Rana temporaria $^{\text {to }}$ & Serbia & KR136358 \\
\hline Rana temporaria & Serbia & KR136359 \\
\hline Rana temporaria & Serbia & KR136360 \\
\hline Rana temporaria & Spain & JF299206 \\
\hline Rana temporaria & Germany & DQ283129 \\
\hline Rana temporaria & France & KC977170 \\
\hline Rana temporaria & Russia & AB058882 \\
\hline Rana temporaria & Russia & KC977157 \\
\hline Rana temporaria & Sweden & KJ128957 \\
\hline Rana temporaria & Ukraine & КC977158 \\
\hline Rana temporaria & Czech Republic & AB685766 \\
\hline Rana temporaria & Italy & KC977178 \\
\hline Rana temporaria & Croatia & KC977177 \\
\hline Bufo bufo & Serbia & KR136361 \\
\hline Bufo bufo & Serbia & KR136362 \\
\hline Bufo bufo & Serbia & KR136363 \\
\hline Bufo bufo & Portugal & AB159591 \\
\hline Bufo bufo & Italy & AY555021 \\
\hline Bufo bufo & Italy & AY555020 \\
\hline Bufo bufo & Turkey & AY840247 \\
\hline Bufo bufo & Turkey & AY555025 \\
\hline Bufo bufo & Greece & AY555022 \\
\hline Bufo bufo & Greece & AY840230 \\
\hline Bufo bufo & Croatia & JX218105 \\
\hline Bufo bufo & Ukraine & JX218100 \\
\hline Bufo bufo & Austria & JQ348765 \\
\hline Bombina variegata & \multicolumn{2}{|c|}{ HE794027 } \\
\hline
\end{tabular}

